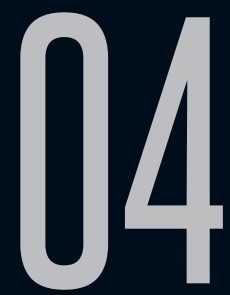

\title{
SAGRADO, DE TOMÁS ELOY MARTÍNEZ: FIGURAS E MITOS REALISTA MARAVILHOSOS ${ }^{1}$
}

Andre Mitidieri (UESC)

Luciana Mazzutti (IFBaiano)

Recebido em 30 set 2018. Andre Mitidieri é Doutor em Letras, área de Aprovado em 10 mar 2019. concentração em Teoria da Literatura, pela Pontifícia Universidade Católica do Rio Grande do Sul (PUCRS). Pós-Doutorado em Estudos Literários pela Universidade Federal do Rio Grande do Sul (UFRGS). Professor Titular de Literaturas Vernáculas no Curso de Letras da Universidade Estadual de Santa Cruz (UESC), nas áreas: Teoria Literária, História e Literatura. Produções bibliográficas mais significativas: MITIDIERI, André; CAMARGO, Flávio Pereira (Org) Literatura, homoerotismo e expressões homoculturais. Ilhéus: EDITUS, 2015. MITIDIERI, André Luis; SILVA, Denise Almeida; CALEGARI, Lizandro Carlos. O Quintana que (quase) ninguém viu. Frederico Westphalen: EdURI, 2012. MITIDIERI, André Luis. Como e porque (des)ler os clássicos da biografia. Porto Alegre: EDIPUCRS; IEL, 2010. V. Participação em grupos de pesquisa, grupos de trabalho, núcleos ou centros de pesquisa ou estudos Grupo de Pesquisa (CNPq): O Espaço Biográfico no Horizonte da Literatura Homoerótica - Líder do grupo; Programa de Extensão Revisões do Cânone (UESC) Coordenador. Em 2017, Melhor Trabalho de Iniciação Científica/Orientação de Tales Santos Pereira, PróReitoria de Pós-Graduação e Pesquisa da UESC. Em 2016, Destaque da Iniciação Científica/Orientação

1 Título em espanhol: Sagrado, de Tomás Eloy Martínez: figuras y mitos realista maravillosos. 
de Leandro Souza Borges Silva, Pró-Reitoria de PósGraduação e Pesquisa da UESC. Em 2015, Destaque da Iniciação Científica/Orientação de Tiago Calazans Simões, Pró-Reitoria de Pós-Graduação e Pesquisa da UESC. Em 2014, Melhor Projeto de Pesquisa/ Orientação de Tales Santos Pereira, Pró-Reitoria de Pós-Graduação e Pesquisa da Universidade Estadual de Santa Cruz (UESC). Em 2012, Homenagem Especial, XXXIII Feira do Livro de Alegrete e Troféu Mario Quintana, Diretoria de Cultura - Prefeitura Municipal de Alegrete. Áreas de interesse de pesquisa: Teoria literária, Diversidade sexual e de Gênero, Literatura Brasileira, Literaturas Hispânicas, Estudos Culturais. Lattes: http://lattes.cnpq.br/5629822206205508.

Luciana Mazzutti é Mestre em Letras: Linguagens e Representações (UESC), com a pesquisa financiada pela Coordenação de Aperfeiçoamento de Pessoal de Nível Superior (CAPES): A insólita hibridação do romance Sagrado, sob orientação do Prof. Dr. André Mitidieri. Professora EBTT-DE, em outubro de 2016 do Instituto Federal de Educação, Ciência e Tecnologia Baiano e, atualmente, Coordenadora de Pesquisa Substituta, do Instituto, Campus Alagoinhas. Áreas de atuação: Língua Portuguesa, Língua Espanhol e Respectivas Literaturas. Produções bibliográficas mais significativas: MAZZUTTI, LUCIANA HELENA CAJAS; RODRIGUES, INARA. (2016) Um olhar realista maravilhoso a partir d?A varanda de frangipani. Navegações (Impresso) (Porto Alegre), v.8, p.156. MAZZUTTI, L. H. C.; MITIDIERI, André Luis. Expressões conceituais do Insólito no espaço literário sulamericano. Signo (UNISC. Online), v.40, p.21-32, 2015. MITIDIERI, A.; GUIMARAES, L. B.; MAZZUTTI, L. H. C. (2013)Tomás Eloy Martínez e as (des)memórias de Juan Domingo Perón. Letras de Hoje (Online), v.48, p.431-440. Participação em grupos de pesquisa, grupos de trabalho, núcleos ou centros de pesquisa ou estudos Grupo de Pesquisa (CNPq): O Espaço 
Biográfico no Horizonte da Literatura. Áreas de interesse de pesquisa: Teoria literária, Diversidade sexual e de Gênero, Literatura Brasileira, Literaturas Hispânicas, Estudos Culturais. Lattes: http://lattes. cnpq.br/8394792874185199 E-mail: shanbarros@ gmail.com ou luciana.mazzutti@ifbaiano.edu.br

Resumo: Nesta investigação, estabelecemos um diálogo entre a obra literária Sagrado (1969) e a escrita autobiográfica, crítica e jornalística do autor Eloy Martínez, verificando a comunicação que firma com seus possíveis leitores. Destacamos a imbricação que o ficcionista argentino arquiteta ao relacionar a cidade argentina à personagem principal do romance em análise, autenticando o que afirmam, em jornais e publicações argentinos, outros intelectuais de grande porte. Também observamos que a narrativa, entendida como estória ou fábula, configura seus elementos de caráter realista maravilhoso a partir da espacialização ficcional da cidade de Tucumán e na órbita de sua personagem Bío. Esse protagonista, cujo nome intitula o primeiro capítulo da obra literária em estudo, torna-se representativo de uma sociedade repleta de tabus, mitos e tradições. Consideramos, neste ponto da pesquisa, a reterritorialização que, na concepção de Canclini (2003), completa um dos processos responsáveis pela hibridação. Nesse sentido, a personagem principal, em contato com outras "localizações", "relocaliza-se" e ressignifica bens simbólicos, sem desconsiderar a herança tucumana.

Palavras-chave: Insólito; Real Maravilhoso; Realismo Maravilhoso.

Resumen: En esta investigación, establecemos un diálogo entre la obra literaria y la escrita autobiográfica, crítica y periodística de Tomás Eloy Martínez, verificando la comunicación que firma con sus posibles lectores. Destacamos la imbricación que el ficcionista argentino arquitecta cuando relaciona 
la ciudad argentina al personaje principal de Sagrado (1969), autenticando lo que afirman, en periódicos y publicaciones argentinos, otros intelectuales de gran porte. También observamos que la narrativa, entendida como historia o fábula, configura los elementos de carácter realista maravilloso a partir de la espacialización ficcional de la ciudad de Tucumán y en la orbita del personaje Bío. Ese protagonista, cuyo nombre intitula el primer capítulo de la obra literária en estudio, se torna representativo de una sociedad repleta de tabus, mitos y tradicciones. Consideramos, en este punto de la pesquisa, la reterritorialización que, en la concepción de Néstor García Canclini (2003), completa uno de los procesos responsables por la hibridación. En este sentido, el personaje principal, en contacto con otras "localizaciones", "se relocaliza" y resignifica bienes simbólicos, sin desconsiderar la herencia tucumana.

Palabras-clave: Insólito; Real Maravilloso; Realismo Maravilloso.

Em seu primeiro romance, Sagrado, Tomás Eloy Martínez (1969) descreve, aparentemente, as experiências de Bío que, desde o nascimento até a vida adulta, ultrapassa barreiras familiares, sociais, culturais e religiosas. Tornar-se um grande boxeador, atender ao sonho de sua mãe, parece ser seu objetivo, mas a narrativa dá maior ênfase a sua decadência. A ascensão e o declínio do protagonista imbricam-se às condições históricas, político-econômicas e sociais da sua cidade, Tucumán, nesse romance dividido em três capítulos, intitulados respectivamente Bío, Andrés e Boni.

As personagens que constituem a narrativa e contribuem para o desenvolvimento da trama, em sua maioria, fazem parte da família de Bío, o protagonista. A mãe, cujo nome não é mencionado, além de criá-lo atendendo à tradição tucumana, participa diretamente 
da sua vida esportiva, dos seus treinos de boxe. O pai, com pouquíssimas participações na vida do filho, mostra-se importante, principalmente quando o livra da morte. As tias, muitas vezes sem nomes, fazem de tudo para perpetuar a união familiar e as práticas religiosas, vigiando para que todos obedeçam às orientações dadas pela doutrina judaico-cristã. O tio Judas, ao ser pego raspando as pernas, levou a família a ganhar o apelido de "Os Esquisitos".

Outras personagens colaboraram com essa denominação familiar: a mãe, que perfumava os bifes para saírem cheirosos após a digestão; a tia Matilde, que dormia entre caixas de bandagem enquanto as serviçais aplicavam loções de laranjeira para cuidar dos cachos; as avós Adelina - dos duzentos quilos, que desmaiava com as provocações da prima Osório - e Presbiteria, a qual costurou os cantos da boca a fim de parecer-se com Clara Bow, atriz americana de cinema que tinha a boca bem pequena. Além dessas personagens, vale citar Tia Rosa, que bordava sem parar a árvore genealógica da família e, cada vez que alguém nascia ou morria, desfazia o bordado, recomeçando-o incansavelmente, e a solteirona Prima Osório, com quem o protagonista teve sua primeira relação sexual, personagem que afugentava os pretendentes de tanto abraçá-los e beijá-los, em um tipo de amor sufocante. Não menos estranhos, eram o tio Whebe, dono da mercearia onde a família costumava comprar, que dispunha os ganchos das carnes ao contrário; e tio Eloy, o barbeiro, que experimentava cortes esquisitos nos cabelos dos sobrinhos.

Por sua vez, Gosi é uma espécie de "zombi" ou "trickster" que, montado em uma bicicleta, aposta corrida com o pai de Bío e aparece e desaparece da narrativa nos momentos mais oportunos. O verbete "Zombi", sob a autoria de Maximilien Laroche (2007), no Dicionário 
de figuras e mitos literários das Américas (p.687-692), classifica o termo como personagem natural, diferente do "golem", que é artificial. No primeiro caso, trata-se de um "alter ego, um homem que outro homem, por magia ou artifício, trabalha e o submete ao seu governo" (p.691). Trata-se de um ser vivo e morto ao mesmo tempo, figura que varia dependendo da evocação: "em uma lenda africana, em um boato haitiano, numa notícia parisiense ou num filme de Hollywood" (p.687).

A figuração aterradora do zombi, na América Hispânica, pode apresentar-se de três formas: a) um sujeito maléfico; b) alguém comandado porum mestre, sem vontade própria;c)seres inofensivos, educados, simpáticos, mas travessos. Escritores haitianos, filiados ao Realismo Maravilhoso, retiram as características negativas, deixando de apresentá-lo como um estrangeiro, em procedimento de reterritorialização. Segundo Néstor García Canclini (2003), esse ato, precedido da desterritorialização, torna-se um desejo de "fixar signos de identificação, rituais que os diferenciem dos que estão só de passagem, são turistas ou... antropólogos curiosos para entender os cruzamentos interculturais" (p.325). Assim, a concepção de zumbi, em Sagrado (MARTíNEZ, 1969), difere das estabelecidas em outras territorialidades e ganha um novo significado, que compõe a interculturalidade própria da América do Sul, a levar em conta sua história e sociedades.

Segundo Rubelise da Cunha (2007), autora do verbete "Trickster" (p.641-647) no dicionário organizado por Bernd (2007), o termo predomina em estudos das literaturas ameríndias e define uma personagem ambígua e amoral que prega peças, podendo ser humano e animal, criador e destruidor, herói e anti-herói, mas 
também tornar-se vítima das próprias trapaças. No entanto, não se define por oposições binárias e hierárquicas, pois se origina de línguas e memórias culturais que não aceitam essa dicotomia. São seres que possivelmente sofrem mutações, em alguns momentos, considerados mensageiros entre o humano e o divino. A definição precisa impossibilita-se pelas várias formas e comportamentos que a figura assume em diferentes narrativas; mais do que uma conceituação, "é uma projeção da cultura ocidental com o intuito de entender e explicar um universo cultural distinto" (p.642).

Além de conviver com personagens estranhas como essa, muitas delas portadoras de significações figurais ou míticas constantes na cultura sul-americana, Bío conta ainda com os conhecimentos do treinador, Hermegildo Maziotti, que, acompanhado do massagista e do tesoureiro, leva-o para um centro de treinamento e juntos trabalham para que Bío se transforme em boxeador profissional. Após uma luta triunfante, o protagonista conhece Andrés, Severito e Boni, tornando-se amigo inseparável deles. Brigi, matrona da Casa de domesticación, desperta neles o desejo e a revolta pela forma como tratam os homens que servem a casa.

Sagrado (MARTÍNEZ, 1969) insere-se no Realismo Maravilhoso, pois aborda o discurso da realidade americana que, segundo Irlemar Chiampi (1980), "permite determinar as coordenadas de uma cultura, de uma sociedade, de uma linguagem hispanoamericana" (p.13). Essas coordenadas são visíveis no protagonista do romance, que não pode ser analisado fora de sua história pessoal nem das relações que estabelece com o contexto social, a fim de comprovar-se a importância da diversidade cultural estabelecida na sociedade e na família nele representadas. Já 
no início da narrativa, Martínez (1969) insere Tucumán como a realidade social e histórica à qual aponta:

o primeiro momento é eterno porque a primeira palavra é eterna e diz tudo. Essa máxima sempre ocupou um lugar privilegiado nos vestíbulos da minha família, e por mais voltas que the tenham dado, nenhuma das minhas tias pôde substituí-la. Nos anos de vacas magras, quando Tucumán criava tempestades puras e tremores de terra, voavam as tias com as saias alvorotadas a esconder a máxima nos armários e a buscar nos bazares antídotos para afugentá-la. ( p.13) ${ }^{2}$

Ao representar a cidade argentina no romance, Martínez introduz o leitor nesse universo ficcional e naturaliza eventos extranaturais. Sem assustar o leitor, o Insólito é estranho e conhecido; o receptor/leitor percebe o "oculto" como se estivesse sempre ali, presente, "escondido", ou seja, é familiar a ele. Após apresentado o espaço com características marcantes do Realismo Maravilhoso, é a vez de abordar o protagonista. Para tanto, o escritor argentino faz seleções que não devem ser consideradas casuais, pois, segundo Zilá Bernd (2007),

como se sabe, a escolha dos mitos pelos escritores não é inocente e sua inscrição no tecido literário é prevista para causar um impacto político e social. O imaginário no qual os mitos são apresentados mascara muitas vezes seu poder de desestabilização e contribui para a renovação social, lá onde os discursos racionais falharam. (p.545)

2 Texto-fonte: "El primer momento es eterno porque la primera palabra es eterna y dice todo. Esa máxima ha ocupado siempre un lugar privilegiado en los vestíbulos de mi familia, y por más vueltas que le hayan dado, ninguna de mis tías ha podido reemplazarla. En los años de vacas flacas, cuando Tucumán criaba puras tempestades y temblores de tierra, volaban las tías con las polleras alborotadas a esconder la máxima en los armarios y a buscar en los bazares contra-venenos para ahuyentarla" (MARTÍNEZ, 1969, p.13). 
Ao discorrer sobre o verbete "recém-nascido", no dicionário por ela organizado, Bernd (2007) assinala a eficácia do mito em textos literários, uma vez que fundamenta a ideia de renovação e recomeço: "A figura do nascimento de uma criança está, pois, desde os primórdios, associada à regeneração, à redenção e à salvação de uma determinada coletividade" (p.547). O anúncio do nascimento do filho do protagonista morto, em Écuê-Yambo-Ô, de Carpentier, segundo a estudiosa brasileira, configura uma "projeção utópica", relacionada a mudanças ocorridas no continente sul-americano, durante a Revolução Cubana.

O romance em estudo traz também um nascimento, ou melhor, um recém-nascido, que talvez venha para evidenciar a possibilidade de redenção, renovação e regeneração da sociedade tucumana. Bío conta um mês de nascido quando quase morre ao provar sorvete de amendoim. Seu pai, sua mãe e suas tias desesperam-se, pois o menino não comia e recusava qualquer líquido a ele oferecido. Sendo a morte iminente, após todas as tentativas para salvá-lo dentre elas, promessas e simpatias -, sem obterem resultado algum,

mamãe e as vizinhas conjuraram os Pregos de Cristo, amarraram Pôncio Pilatos em seus lenços e sacrificaram no altar do Senhor sabiás amarelos trazidos de Santa Cruz, os primeiros brotos de cana, a geleia que minha avó arrebatava ao coração das maçãs. Mas eu não deixava de desperdiçar a água legada por minha mãe e recusava os milagres: esgotei cisternas de minhas entranhas, lancei mão dos sortimentos de minhas moléculas. E no meio de tal seca, tomou conta de minha casa o vício do pranto. (MARTINEZ, 1969, p.16)

3 Texto-fonte: "Mi mamá y las vecinas conjuraron a los Clavos de Cristo, ataron en sus pañuelos a Poncio Pilato y sacrificaron en el altar del señor los tordos amarillos traídos 
Ainda com base no dicionário organizado por Bernd (2007), a partir da definição desenvolvida por Nubia Jacques Hanciau (p.282-288) para o verbete "feitiçaria", buscamos entender o valor simbólico do poder das metamorfoses e reutilizações próprias do "constante perambular, no indefinível e na passagem, de um estado para uma nova forma" (HANCIAU, 2007, p.287), em que tudo faz parte do incompreensível, inapreensível, impalpável. Associamos essa elucidação às práticas em que se mesclam crenças cristãs e não-cristãs, intrínsecas e admissíveis nos eventos insólitos, mas talvez desafiadoras para o pensamento moderno de tipo analítico, segundo Canclini (2003), "acostumado a separar binariamente o civilizado do selvagem, o nacional do estrangeiro, o anglo do latino etc." (p.XXXIII).

A moléstia vivida por Bío é desconhecida às lentes da ciência e da medicina, mas não aos olhos de seus conterrâneos, a miscelânea religiosa, por um lado, assinalada por promessas aos santos e, por outro, pelas simpatias e crendices populares, representa a diversidade cultural e religiosa presente na América do Sul, corroborando para que o leitor/receptor naturalize o extraordinário e não questione o Insólito. $\mathrm{O}$ amparo em crenças tradicionais ou místicas mostra como o núcleo familiar tucumano exemplifica a hibridação cultural que cerca o contexto sul-americano e permite a percepção do sujeito como sua parte integrante, assegurando a ideia de Canclini (2003) sobre o fato de as culturas populares não se extinguirem, sendo preciso buscá-las em outros lugares ou não-lugares.

de Santa Cruz, los retoños tempranos de la caña, la jalea que mi abuela arrebataba al corazón de las manzanas. Pero yo no cesaba de derrochar el agua legada por mi madre y rehusaba los milagros: agoté aljibes de mis vísceras, eché mano a los surtidos de mis moléculas. Y en medio de tal sequía, prendió en mi casa el vicio del llanto" (MARTINEZ, 1969, p.16). 
Desse modo, Martínez (1969) apresenta as dúvidas de Bío sobre a suposta sacralidade tucumana e como essa personagem migra na tentativa de reterritorializar-se, o que teria a ver com:

Os cruzamentos intensos e a instabilidade das tradições, bases da abertura valorativa, podem ser também [...] fontes de preconceitos e confrontos. Por isso, a análise das vantagens ou inconvenientes da desterritorialização não deve ser reduzida aos movimentos de ideias ou códigos culturais [...]. (CANCLINI, 2003, p.326)

Retomamos as contribuições de Canclini (2003) quando, em seu estudo, admite que o processo de migrações da América do Sul é assimétrico e esclarece que o objetivo dos processos de hibridação não resulta em conceber um sujeito que entra e/ou sai pacificamente da hibridação, mas que transita da desterritorialização à reterritorialização (ou seja, sai do campo e ingressa no urbano) com espontaneidade. Nesse trajeto, talvez seja decisivo continuar a "construir princípios teóricos e recursos metodológicos [para] tornar este mundo [...] mais convivível em meio a suas diferenças, e a aceitar o que cada um ganha e está perdendo ao hibridar-se" (p.XXXIX).

Nessa perspectiva, o Real Maravilhoso, basilar na elaboração do Realismo Maravilhoso, remete ao conceito ontológico, visto que "não é o resultado da criação do artista através de determinado procedimento formal, pois ele está ali" (ESTEVES; FIGUEIREDO, 2010, p.405). A diferença encontra-se na capacidade de perceber os elementos maravilhosos, assimilação possível através do reconhecimento do sujeito na cultura; caso contrário, passam sem ser percebidos ou, ainda, equivocadamente compreendidos, como algo essencialmente mágico ou deformado pelo escritor. 
Em Sagrado (MARTínEZ, 1969), o contexto social, cultural e religioso é exposto de maneira que leva o leitor à naturalização das ocorrências ficcionais, extraordinárias, irreais e/ou imaginárias. Os princípios em torno do sexo, como uma prática suja e pecaminosa, assim como a disciplina perante a obediência às tradições, à igreja e aos preceitos impostos pela sociedade, constituem não só as personagens, mas, principalmente, a construção do espaço social e intercultural que, por sua vez, estabelece marcas significativas da escrita realista maravilhosa de Martínez.

Quanto ao contexto socioeconômico representado na obra literária, o estudo desenvolvido por Daniel Campi (2003) - "Azúcar y trabajo. Coacción y mercado laboral en Tucumán" - assinala como o poder estabelecido nessa sociedade determinava obediência aos donos dos engenhos açucareiros, que comandavam a província argentina:

o empenho em constituir uma massa de assalariados modernos exigia impor às classes subalternas os valores subjetivos da elite sobre o trabalho, o uso do tempo vago, o ócio; especificamente, a legitimidade do direito à propriedade dos patrões sobre a força de trabalho. (CAMPI, 2003, p.250) ${ }^{4}$

Mesmo sob a determinação das elites tucumanas, os trabalhadores "se comportaram como atores históricos com capacidade para incidir em suas condições de existência" (CAMPI, 2003$, p.251) $)^{5}$. O pensamento libertário dos proletários instituiu

4 Texto-fonte: "el empeño en constituir una masa de asalariados modernos exigía imponer en las clases subalternas las valoraciones subjetivas de la élite sobre el trabajo, el uso del tiempo, el ocio; especificamente, la legitimidad del derecho de propiedad de los patrones sobre la fuerza de trabajo" (CAMPI, 2003, p.250).

5 Texto-fonte: "se comportaron como actores históricos con capacidad para incidir en sus condiciones de existencia" (CAMPI, 2003, p.251). 
sérios obstáculos para que a disciplina e moralização elitista obtivessem sucesso. Essa postura contestadora associa-se ao evento insólito que, no romance em estudo, descreve uma possível tomada de poder através da invasão das formigas (trabalhadores) temida pelo casal de idosos (elite):

- Somos seus únicos inimigos - diz o velho, abraçado ao regador -. Entregamos aos bombeiros um esquema de suas galerias, uma lista de suas rainhas e um mapa de seus ninhos. Avisamos-lhes que têm campos de treinamento em Lules e uma frota de tanques para tomar o poder. Ninguém nos ouve, ninguém quer acreditar em nós. Estamos desesperados. Na fonte do quintal, as formigas instalaram um quartel general, os aeródromos e os parques de diversões. Comeram nossa plantação de rosas e começaram a morder as escadas. A única defesa é irriga-las. Já não se assustam com a fumaça nem com o veneno (MARTíNEZ, 1969, p.179) ${ }^{6}$.

Vinculado à história tucumana, como vimos, esse fato romanesco confirma a afirmação de Chiampi (1980) sobre o Realismo Maravilhoso, segundo a qual, todo e qualquer elemento relacionado com o humano, ao ser considerado extraordinário ou quando escapa de uma explicação racional e do curso ordinário das coisas, recebe a conotação de milagre e passa a obter aceitação do indivíduo comum. A segunda atribuição, apontada pela estudiosa acerca dessa modalidade do Insólito,

6 Texto-fonte: "[...] - Somos sus únicos enemigos - dice el viejo, abrazado al irrigador -. Hemos entregado a los bomberos un plano de sus galerías, una lista de sus reinas y un mapa de sus nidos. Les hemos avisado que tienen campos de entrenamiento en Lules y una flota de tanques para tomar el poder. Nadie nos oye, nadie quiere creernos. Estamos desesperados. En la fuente del patio, las hormigas han instalado el cuartel general, los aeródromos y los parques de diversiones. Nos han comido los rosales y han empezado a morder las escaleras. La única defensa es irrigarlas. Ya no se asustan del humo ni del veneno. (MARTÍNEZ, 1969, p.179) 
refere-se a tudo o que é inumano e se produz pela intervenção dos seres naturais.

No romance em análise, o culto a um animal, praticado pelo pai de Bío, demonstra extraordinariedade. A provável morte do filho relaciona-se com a expressão russa que dá abertura ao romance - Knovz smovz ka pop - nesse contexto, a significar que todo mal será castigado:

'Castigo de Deus' - disse papai - por ficar na jogatina fazendo um papelão'. Como penitência, apalpou a burra e, para livrá-la de sua dor, encheu o chapéu com o leite passado. Esse foi o primeiro milagre do beato San Martín, cuja vassourinha invocou papai naquele momento: do céu recebeu a ordem para que me oferecesse o leite, e assim que o provei, fui surrupiado da morte. (MARTINEZ, 1969$, p.16 $)^{7}$

Ao salvar Bío com o leite da burra, o pai, grato pelo milagre, ajoelha-se e a denomina María Santísima. Toda vez que precisa ordenhar a quadrúpede, como forma de punição pelos pecados cometidos, tolera ser castigado com coices. Ao descrever a saga da família para livrar o recém-nascido da morte, o narrador enfatiza a relação inabitual entre o homem e o animal:

'Oh, Maria Santíssima', ele a chamava desde a área do pênalti, e a burra trotando em direção a ele com manhas de noiva: não se deixava tocar até que papai não lhe rendesse culto, ajoelhando-se e suportando os chutes de boas vindas. Aquele leite

7 Texto-fonte: "'Castigo de Dios' - dijo el papá -, por quedarme en la canchita haciendo un papelón.' En penitencia tanteó a la burra, y para descargarla del dolor llenó el sombrero con la leche atrasada. Ese fue el primer milagro del beato San Martín, cuya escobita invocó el papá en aquel momento: del cielo recibió la orden de que me ofrendara la leche, y apenas la probé, fui sonsacado de la muerte". (MARTINEZ, 1969, p.16) 
me engordou a carapaça e revigorou para sempre a minha flora intestinal. (MARTÍNEZ, 1969, p.17) ${ }^{8}$

As proibições e restrições sociais atingem Bío, educado para reprimir pensamentos que causem alguma excitação ou desejo, e cujo objetivo é não cometer "pecados". Ao atender as orientações que recebe das personagens femininas da família, atribui nomes e significados às coisas. A fim de dissimular sua curiosidade quanto ao sexo, confere tantas significações ao momento vivido, que pensa existir uma eternidade prazerosa e a ela se entrega. Ao término do ato sexual, retorna à realidade castradora, onde mãe, tias e avós impunham-lhe o comportamento que julgavam adequado à sociedade local:

Encontrei a vida rasteira que não se sabia viver, nem se apaixonar, nem dizer: 'Amorzinho, estou aqui, pega de mim tudo que você quiser porque não tenho coragem de negar-me'. E logo que vi a verdadeira vida bebendo a água das fontes nas praças, sem me preocupar com os micróbios nem com as pestes, mal a vi três dias seguidos de farra, sem pensar no sono nem no cansaço, e a ejacular dez vezes em uma única noite sem afligir-se pelas noites seguintes, mal vi a vida livrar-se do que dirão como um fogo de artifício, então o paraíso foi-me apagado de um golpe, demonstrou sua inutilidade e sua lerdeza [...] E assim, pois, senti-me viver, recobrei meus entornos e minhas origens e meus azedumes hereditários. (MARTINEZ, 1969, p.23) ${ }^{9}$

8 Texto-fonte: "'iHola, María Santísima!', la llamaba desde el área penal, y la burra se le acercaba trotando, con melindres de novia: no se dejaba tocar hasta que el papá no le rendía culto, arrodillándose y soportando las coces de bienvenida. Aquella leche me engordó el velamen y asoleó para siempre mi flora intestinal". (MARTINEZ, 1969, p.17)

9 Texto-fonte: "Hallé la vida rastrera que no sabía vivirse, ni enamorarse, ni decir: 'Amorcito, aquí estoy, tomá de mí todo lo que quieras porque no tengo el coraje de negarme'. Y apenas vi a la verdadera vida bebiendo el agua de los surtidores en las plazas, sin preocuparme por los microbios ni las pestes, apenas la vi tres días seguidos de 
Bío descreve detalhadamente sua experiência sexual e finaliza com a expressão "tive um dia de paraíso" (MARTINEZ, 1969, p.17) ${ }^{10}$. O termo "paraíso", que consta na compilação elaborada por Bernd (2007), sob a autoria de Henriete Karam (p.506-511), "designa um lugar de delícias, aprazível, edênico, apresentando correspondência tanto com o Éden [...] quanto com o céu" (p.506) e significações relativas ao espaço físico e ao estado da alma. A sensação que Bío experimenta atende à segunda condição, pois o local não é destacado, passa despercebido, diferentemente dos sentimentos que inundam o protagonista. Para Karam (2007), "a ideia de paraíso (de acordo com as culturas ameríndias) encontra-se representada no mito da terra sem mal" (p.507), lugar privilegiado e perfeito, onde espaço e tempo fazem com que o sujeito ascenda ao plano celestial e os deuses desçam ao mundo terreno.

Conforme Regina Zilberman (1994, p.12-34), durante muito tempo, descobridores, navegantes e cronistas acreditavam que o Jardim do Éden se encontrava na América. Após a chegada de portugueses e espanhóis em solo americano, as escritas correntes mencionavam um espaço rico em flora, fauna e, principalmente, minerais e pedras preciosas, verdadeiro paraíso material. É o caso de Américo Vespúcio (Apud ZILBERMAN, 1994), ao descrever as paisagens paradisíacas do Novo Mundo:

Esta terra é muito amena; cheia de inúmeras árvores verdes, e muito grandes, e nunca

jolgorio, sin pensar en el sueño ni en el cansancio, y eyacular diez veces en una sola noche sin afligirse por las noches siguientes, apenas vi a la vida zafarse del qué dirán como una caña voladora, entonces el paraíso se me borró de un saque, demostró su inutilidad y su torpeza. [...] Y así, pues, me sentí vivir, recobré mis alrededores y mis orígenes y mis vinagreras hereditarias. (MARTINEZ, 1969, p.23)

10 Texto-fonte: "tuve un día de paraíso" (MARTINEZ, 1969, p.17). 
perdem folha, e todas têm odores suavíssimos, e aromáticos, e produzem inúmeras frutas, e muitas delas boas ao gosto e saudáveis ao Corpo, e os campos produzem muita erva, e flores, e raízes muito suaves, e boas, que umas vezes me maravilha de odor suave de ervas, e das flores, e do sabor dessas frutas, e raízes, tanto que em mim pensava estar perto do Paraíso terrestre. (p.15)

Zilberman (1994) afirma que o imaginário da época dava significado e sucesso editorial ao texto de Vespúcio: "a América se populariza enquanto tem condições de ser o que os europeus esperam dela" (p.16). Criava-se e recriava-se o mito do Paraíso, propagado até o século XVII, através da literatura que o difundia no Velho Continente. Relocalizava-se a concepção do Éden para conceber a ressignificação dada à América do Sul, quando, durante a colonização do continente, a natureza exuberante encontrada pelos exploradores europeus "atraía, porque podia ser explorada e facultava o enriquecimento de seus ocupantes" (ZILBERMAN, 1994, p.33).

Sagrado (MARTíNEZ, 1969) veicula a denominação de Tucumán como Jardín de la República, um registro do colonizador já reterritorializado, a partir de suas heranças e bens simbólicos, no momento em que a vegetação vasta e diversa da cidade e seus arredores teria impressionado os espanhóis. O designativo, contemplado por Martínez, ainda abrange a canção Al Jardín de la República, composição de Virgilio Carmona cujo fragmento - "Para as outras, não; pras do norte, sim; para as de Simoca, minhas ânsias loucas de estar ali"11 - entra de acordo com o que afirma Canclini (2003) sobre a reterritorialização:

11 Texto-fonte: "[...] Para las otras no, pa' las del norte si, para las de Simoca, mis ansias locas de estar alli". 
Nos intercâmbios da simbologia com os circuitos internacionais de comunicação, com as indústrias culturais e as migrações, não desaparecem as perguntas pela identidade e pelo nacional, pela defesa da soberania, pela desigual apropriação do saber e da arte. Não se apagam os conflitos, como pretende o pós-modernismo neoconservador. Colocam-se em outro registro, multifocal e mais tolerante, repensa-se a autonomia de cada cultura - às vezes - com menores riscos fundamentalistas. (p.326)

Registrada de outra forma em Sagrado (MARTíNEZ, 1699), a imagem fixada naquelas escritas dos exploradores europeus se reterritorializa: ao encontrar Brigi, Bío tem acesso a sensações que - levam a inúmeras possibilidades de chegar ao paraíso, em seu caso, em uma concepção mais mundana do que celestial. Processos de hibridação como esse, segundo Canclini (2003), enfrentam resistências por gerarem insegurança nas culturas e conspirarem contra sua autoestima etnocêntrica. Torna-se "necessário registrar aquilo que, nos entrecruzamentos, permanece diferente" (p.XXXIII).

A propósito, Carmen Perilli (2010), em "La patria entre naranjos y cañaverales. Tucumán y el primer centenario", menciona curiosos e fascinados cartógrafos que buscavam seduzir seus receptores através do imaginário território paradisíaco, em que selva e montanhas conviviam, onde habitavam o índio livre e o criollo submisso. A autora destaca a literatura elitista, voltada à cultura hispânico-europeia, na qual se apresenta um trabalhador que se satisfaz servindo às imposições do patrão de forma harmoniosa e a elas adaptado. A estreita vinculação entre família, cultura e poder preservava e difundia os valores considerados patrimônio local, os 
donos dos engenhos de açúcar ocupavam os postos políticos na província e na capital tucumanas.

Juan B. Terán, mencionado por Perilli (2010), proporciona argumentos geográficos, históricos e simbólicos sobre o espaço tucumano:

\begin{abstract}
Descreve o norte argentino como uma extensa zona povoada, constituída pelas províncias de Tucumán, Santiago del Estero, Salta, Catamarca y Jujuy que, em sua totalidade, reúne, mais de um milhão de habitantes. O centro 'de atração natural' desta região é a cidade de San Miguel de Tucumán 'terra de encontro' de civilizações que emerge como urbe de 'vida industrial e agrícola ativa e inteligente' e com um capital educativo apreciável. (TERÁN, Apud PERILLI, 2010) $)^{12}$
\end{abstract}

Os argumentos de Terán enfatizam a influência hispânica que consolidou uma configuração sociocultural marcada pelo ideário cristão e, portanto, repressor no que concerne à sexualidade. A região tucumana apresenta "fenômenos próprios", ainda que, durante um longo período, sua história tenha ficado à margem, pois se tratava do interior argentino, ocupando posição de sombra da capital, Buenos Aires. Os enlaces políticos, econômicos, sociais e o crescimento dos engenhos de açúcar fizeram com que a província de Tucumán se destacasse no cenário nacional; o movimento de resistência e a nostalgia do passado não impediu a projeção para o futuro.

12 Texto-fonte: "Describe el Norte como una extensa zona poblada, constituida por las provincias de Tucumán, Santiago del Estero, Salta, Catamarca y Jujuy que, en su totalidad, reúnen más de un millón de habitantes. El centro 'de atracción natural' de esta región es la ciudad de San Miguel de Tucumán 'tierra de encuentro' de civilizaciones que emerge como urbe de 'vida industrial y agrícola activa e inteligente' y con un apreciable capital educativo" (TERÁN, Apud PERILLI, 2010). 
Catolicismo e espiritualismo passam a representar as bandeiras contra ideias laicas, sustentadas pelo socialismo e pelo radicalismo (formação política nacional), considerados "bárbaros" pela sociedade dominante. Perilli (2010) conclui que predomina a concepção de cultura superior baseada no espiritual sem causar prejuízo ao desenvolvimento científico: classificar, ordenar. A tentativa consiste em inventar uma Tucumán que, no decorrer do tempo, progrida, relacionando-se com o pensamento de Canclini (2003) sobre a vigência dos perfis nacionais em algumas áreas de consumo, sobretudo nos campos em que cada sociedade dispõe de ofertas próprias.

Segundo declara Martínez (1997), em entrevista a César Güemes publicada no periódico La Jornada, o país era a sexta potência industrial do mundo, superava a França no número de automóveis e o Japão, em telefones. Especialistas afirmavam que, até o final do século $\mathrm{XX}$, seria estabelecida uma grande competição com os Estados Unidos, o que nunca aconteceu devido às crises econômicas e às ditaduras, mas a imagem de potência, construída e enraizada, permanece até a atualidade.

O ficcionista argentino compara o país a Eva Perón que, embalsamada, não sofre deterioração, mas também não muda, não evolui. No que diz respeito à produção literária, continua a valorizar a escrita nos velhos moldes europeus. O escritor afirma que, embora a crítica nacional reconheça a literatura do Rio da Prata, a sua escrita é tributária da incaica, pois vem da região Norte do país, e menciona que sua esposa, a venezuelana Susana Rotker, algumas vezes, quando pegava táxis em Buenos Aires, era questionada pelos motoristas se era sul-americana. Nessa 
perspectiva, compactuamos com a conclusão de Canclini (2003) ao reconhecer que a hibridação é um conjunto de processos, muitas vezes conflitivos, no qual "os cruzamentos intensos e a instabilidade das tradições, bases da abertura valorativa, podem ser também em condições de competição profissional - fonte de preconceitos e confrontos" (p.326).

Os romances martinezianos objetivam demonstrar até que ponto podem ser considerados sul-americanos. Nesse sentido, Sagrado (MARTíNEZ, 1969) apresenta a origem de Tucumán nas entrelinhas e, para entendê-la, buscamos apoio em um dos seus primeiros historiadores, Arsenio Granillo, que escreveu, em 1870, Província de Tucumán. Publicado em 1872, o estudo visava mostrar diversas possibilidades de que dispunha a província e apresentava riquezas aos imigrantes (estrangeiros) que vislumbrassem a possibilidade de explorar seus recursos. Granillo (1872) aborda, desde o descobrimento, a etimologia do nome dado à região, seus aspectos geográficos e, ainda, o comportamento da sociedade tucumana.

Segundo Granillo (1872), o primeiro espanhol a adentrar em terras tucumanas foi Don Diego Rojas que, em 1543, tomou conta do Valle de Calchaquí. Após a invasão, matança e aprisionamento dos índios, o local passou a ser denominado Barco de Ávila. Somente em 1565, fundou-se San Miguel de Tucumán, até então, um distrito de Santiago del Estero, tardando cento e vinte anos para que atingisse a atual extensão territorial. O nome dado à província tucumana provém do cacique inca Tucman, líder de muito prestígio na região, e de ahaho que, na língua dos calchiquíes, significa povo, logo, povo de Tucman. Embora chamada de Nueva Andalucía pelos conquistadores, o nome do inca, mesmo que alterado, prevaleceu: 
Hoje o que se conhece com o nome de Tucumán é unicamente o território compreendido entre as Províncias de Santiago del Estero, Catamarca e Salta, que tem pouco mais, ou menos, cinquenta léguas de sul a norte, e quarenta de nascente a poente (GRANILLO, 1872, p.6) ${ }^{13}$.

Podemos traçar um paralelo entre o protagonista do romance martineziano, Bío, e o líder inca, Tucman, pois, relacionados diretamente com seu lugar de origem, defendem a terra, independente dos males que possam recair sobre eles. Tucman enfrentou a colonização espanhola, a imposição de costumes e cultura. Bío, por sua vez, contesta as exigências sociais, culturais e religiosas; no entanto, passa parte de sua vida atendendo às tradições. Ao perceber o domínio que a família/sociedade exercia sobre suas escolhas, afasta-se da cidade natal, mas sempre busca uma forma de retornar. Tanto em Sagrado (MARTíNEZ, 1969) como na história de Tucumán, a vida do sujeito tucumano vincula-se ao mundo agrícola:

a agricultura é uma indústria que estreita mais e mais os vínculos sociais do homem, pelo muito que solicita o contato contínuo com os demais; e acostumando-o a vencer com o trabalho os inconvenientes que lhe propõe a natureza, faz com que se habitue à vida laboriosa, manancial inesgotável da riqueza e moralidade [...] O agricultor exercita suas forças musculares nos labores da terra, sem que suas paixões se exaltem. (GRANILLO, 1872, p.129) ${ }^{14}$

13 Texto-fonte: "Hoy lo que se conoce con el nombre de Tucuman, es unicamente el territorio comprendido entre las Provincias de Santiago del Estero, Catamarca y Salta, que tendrá poco mas ó menos cincuenta leguas de Sud á Norte y cuarenta de Naciente a Poniente" (GRANILLO, 1872, p.6)

14 Texto-fonte: "La agricultura es una industria que estrecha más y más los vínculos sociales del hombre, por cuanto reclama el contacto continuo con los demás; y 
Segundo o historiador, o trabalho com a terra é capaz de "domesticar" o ser humano, faz com que aprenda a lidar com suas instabilidades e decepções; o sucesso e o progresso dependeriam das tradições sociais e religiosas pré-estabelecidas. Granillo (1872) afirma que o trabalhador tucumano deveria fé e obediência ao catolicismo (hispânico-europeu). Por sua vez, a personagem principal do romance em análise depara-se diversas vezes com situações que exigem determinado posicionamento. Seguir as tradições judaico-cristãs seria a condição primordial para que alcançasse o êxito social e familiar. Em certa passagem da narrativa, ao descer as escadas do corredor que levava os homens até a chamada "entrada do paraíso", nota que

a cara da Brigi era invisível por causa do sacro resplendor que lhe passava por adiante, o nariz estava no escuro e adiantada em direção do trono e as dominações da Passagem. Ela sorriu para mim, virgem e madonna, pilar, mercedes e pompeia, mas a gritaria dos tucanos, dos cachorros e das rolinhas que chegavam abraçadas ao paraíso cortou-lhe o sorriso. Vi também ao papai brigando com o Gosi [...]. (MARTÍNEZ, 1969, p.22) ${ }^{15}$

Bío sente-se seduzido, mas não pode ceder; a sociedade não aprova a sua relação com madonna, uma prostituta. A gritaria dos animais, vinculados aos protestos e reprovações da comunidade acostumbrándolo a vencer con el trabajo constante los inconvenientes que le opone la rebelde naturaleza, le hace habituarse a la vida laboriosa, manantial inagotable de riqueza y moralidad [...] El agricultor ejercita sus fuerzas musculares en los laboríos de la tierra, sin que sus pasiones se exalten" (GRANILLO, 1872, p.129).

15 Texto-fonte: "La cara de la Brigi era invisible a causa del sacro resplandor que se le paseaba por delante, la nariz estaba a oscuras y adelantada hacia los tronos y las dominaciones del Pasaje. Ella me sonrió, virgen y madonna, pilar, mercedes y pompeya, pero el griterío de los tucanes, de los perros y de las torcazas que llegaban abrazados al paraíso le cortó la sonrisa. Vi también al papá peleándose con el Gosi" [...]. (MARTÍNEZ, 1969, p.22) 
tradicional faz com que o protagonista imagine "Saladino levantar as muralhas de Jerusalém, as tribos diaguitas remontarem as cataratas do rio Salí no princípio dos tempos" (MARTíNEZ, 1969, p.23) ${ }^{16}$. Se os bens simbólicos hibridizados reconfiguram uma condição outra, elaborada nos entrecruzamentos e intercâmbios culturais, a fim de não se deixar levar pela sedutora Brigi, a personagem principal relaciona a cidade bíblica aos povos indígenas independentes (conquistados pelo império incaico e a ocuparem o Valle Calchaquíes, situado nos atuais territórios argentinos de Jujuy, Salta e Tucumán), bem como ao curso das águas que, além das duas últimas províncias referidas, banham Catamarca, Córdoba e Santiago del Estero.

Contudo, o desmascaramento das opiniões sociais e convencionais do narrador-personagem está presente nos silêncios ou em momentos destinados a divagar e ter as próprias impressões do mundo. Quando se deita para dormir ou em "isolamento mental", demonstra seus pensamentos frente às imposições sociais e religiosas. Às vezes, chega a levantar hipóteses sobre o que realmente faria se fosse livre; em outras, narra fatos só realizados em sua mente, para se sentir solto e "dono" de sua vida. A revolta contra as designações da sociedade revelam-se ao mencionar todos os males que gostaria de praticar como resposta a sua infância castrada por convenções. As experiências, os questionamentos próprios de sua idade, os castigos e observações perante imposições de seus familiares são repletos de contestações:

Tudo siga pela ordem, conforme a fila indiana e sua cronologia. Que chegue em ordem o conto 16 Texto-fonte: "vi a Saladino alzar las murallas de Jerusalén, a las tribus diaguitas remontar las cataratas del río Sali en el principio de los tiempos". (MARTíNEZ, 1969, p.23) 
da minha infância despedaçada pela opinião pública, cevada na burguesia pelos meus entornos de bolinhos fritos e tardes de chá, afelpada pelo pressentimento da Brigi que ai, ia tirar-me a pureza como uma venda suja. Não faça aquilo, a noção do bem se encarnou contra a minha pobre pessoa em idade escolar, passeou-me como gravatinhas borboletas e camisas engomadas diante das minhas tias genealógicas, a tias literatas que me barbearam com um vidro toda a vontade de viver. Brotei do vidro e das contusões feridíssimo de morte: ia levantar as saias das tias clérigos e me mordia a língua, a jogar um sapo morto no decote das tias deputadas e o nó do coração me freava, ia quebrar os pratos da casa, estraçalhar os colchões, despedaçar a honra imaculada de minhas primas e enteadas e robustas avós, mas a fúria e o fogo da minha espécie se me havia dormido, gastava sua paixão nos limbos de outras vidas mais dignas. (MARTÍNEZ, 1969, p.24) ${ }^{17}$

Após sua revolta, a personagem principal manifesta-se em monólogo interior, expõe as possíveis práticas que (certamente) seriam repreendidas pelas tias, ou seja, pelo primeiro grupo da sociedade na qual está inserida. Bío expressa seu desacordo com as determinações/imposições familiares praticadas pelas

17 Texto-fonte: "Todo vaya por orden, según su fila india y su cronología. Que llegue por orden el cuento de mi infancia destrozada por la opinión pública, cebada en la burguesía por mis alrededores de buñuelo y tardes de té, afelpada por el presentimiento de la Brigi que ay, iba a quitarme la pureza como una venda sucia. No hagas aquello, la noción del bien se encarnizó contra mi pobre persona en edad escolar, me paseó como moños y camisas almidonadas delante de mis tías genealógicas, las tías literatas que me afeitaron con un vidrio todas las ganas de vivir. Broté del vidrio y de las magulladuras heridísimo de muerte: iba a levantarle las polleras a las tías clérigos y me mordía la lengua, a echar un sapo muerto en el escote de las tías diputadas y el nudo del corazón me sofrenaba; iba a romper los platos de la casa, a destripar los colchones, a rasgar el honor sin tacha de mis primas y entenadas y robustas abuelas, pero la furia y el fuego de mi especie se me había dormido, gastaba su pasión en los limbos de otras vidas más dignas". (MARTÍNEZ, 1969, p.24) 
personagens femininas de sua família, todas fundamentadas na tradição tucumana e com a justificativa de que somente assim, um dia, seria alguém de respeito e reconhecido. Em seu pensamento, elucida que não passam de conclusões pensadas, porém, nunca executadas. Depois da conturbação mental, rende-se às convenções e declara: "o certo é que eu empreendia minha viagem de volta, terminava por cair no sono com uma invocação ao anjo da guarda" (MARTÍNEZ, 1969, p.24) ${ }^{18}$.

Como forma de clemência aos pensamentos indômitos, Bío retorna, aparentemente submisso a determinações às quais às vezes se mostra contrário, permitindo destacar os conflitos de uma sociedade impregnada de crenças e mitos. Sagrado (MARTíNEZ, 1969) não consiste em um documento histórico, porém evidencia as condições socioculturais e religiosas da submissão com a qual o protagonista constantemente se defronta, pois até o seu pensamento é vigiado. Ele se entrega ao conforto dos desejos e realiza suas vontades mentalmente, mas ao fim e ao cabo, retorna ao seu mundo:

Não nos interessava a realidade que cabe nas palavras, a que está instalada nos escaninhos do abecedário; pretendíamos uma outra cujo horizonte fosse uma ameaça, um cemitério, uma sístole, um buraco, um porém, um clarear, destelhar, quebrar os olhos, um bobo, um ápice, um inteiramente. Amávamos, é certo, todos os fios soltos do universo, sem saber com que cola se grudavam nem qual xadrez jogavam com a gente [...] Desfigurávamos as aparências, ateávamos fogo nas cadeiras para ver se entre tanta algazarra havia

18 Texto-fonte: "lo cierto es que yo emprendía mi viaje de vuelta, terminaba por dormirme con una invocación al ángel de la guardia". (MARTínEZ, 1969, p.24) 
um interstício onde nos encontrássemos inteiros, uma cripta que nos tornasse libres e donos de dizer: 'Isto que conto é o que acontece, com suas vírgulas e pontos, sem traições, apesar da música das palavras que nunca encaixa na música do que acontece'. (MARTíNEZ, 1969, p.132) ${ }^{19}$

Segundo o aporte teórico utilizado no presente estudo, mostram-se bastante significativas a origem e a formação do povo sul-americano, especialmente tucumano, na elaboração do romance Sagrado (MARTÍNEZ, 1969), repleto de efeitos emotivos, ora neutralizados, ora negados no Realismo Maravilhoso. Nessa obra literária, as descrições fazem o papel de convencer e/ou questionar quanto às mudanças radicais sofridas por Bío, que não consegue alcançar a metamorfose social, cultural e religiosa, em função dos desarranjos causais, aos quais, de alguma forma, se sente atrelado.

Atentamos, pois, para marcas representativas da comunidade tucumana, baseada em jogos de influências familiares, sociais e tradicionais, pois Martínez reelabora, por intermédio da ficção, não apenas a pluralidade cultural da sua cidade natal, mas também questões implicadas na temática da América em redescobrimento, uma preocupação desencadeada a partir da Revolução Cubana de 1959. Conforme Irlemar Chiampi (1980), essa imagem marca o mundo imaginário dos escritores que mantêm vivos e/ou como

19 Texto-fonte: "No nos interesaba la realidad que cabe en las palabras, la que está instalada en las casillas del abecedario; pretendíamos una cuyo horizonte fuera una amenaza, un cementerio, un sístole, un ojal, un aunque, un clarear, destellar, quebrar los ojos, un tonto, un ápice, un enteramente. Amábamos, es cierto, todos los hilos sueltos del universo, sin saber con qué engrudo se pegaban ni a qué ajedrez jugaban con nosotros [...] Desfigurábamos las apariencias, les echábamos fuego en las caderas para ver si entre tanto zafarrancho había un intersticio donde nos encontráramos enteros, una cripta que nos volviera libres y dueños de decir: 'Esto que cuento es lo que pasa, con sus comas y puntos, sin traiciones, a pesar de la música de las palabras que nunca encaja en la música de lo que pasa'"; (MARTINEZ, 1969, p.132) 
fontes de inspiração as lendas, os mitos e as crenças de suas respectivas épocas, regiões, nações.

O universo ficcional elaborado na escrita martineziana naturaliza os eventos insólitos, associando o contexto histórico por ele referido às experiências vividas pelo protagonista que, na maior parte das vezes, se submete a determinações impostas. Cabe retomar o binômio desterritorialização/reterritorialização, pois como um dos processos para a hibridação, explica a mobilidade, as negociações e as fusões/ interações/interseções que permeiam Bío e a cidade argentina como um elemento único e singular, a fim de reafirmar a identidade e os bens simbólicos ressignificados. O espaço geográfico e o espaço biográfico de Martínez imbricam-se ao seu protagonista, assinalando a reconstrução e a constituição do espaço híbrido assim representado.

Comoveremos, a fábula ou história de Sagrado (MARTÍNEZ, 1969) realiza determinada espécie de condensação entre o protagonista e a cidade de Tucumán, no entanto, quebrada por mecanismos que promovem a alteridade em sua trama ou discurso. Assim, os diversos narradores desse primeiro romance martineziano - Bío, Andrés e Boni - contestam imposições sociopolíticas, assinalam diversidades étnico-culturais e ironizam práticas religiosas judaicocristãs, confrontando-as a transgressões que podem até merecer castigo, mas não deixam de ocorrer. Já a figuração das personagens contribui para com sua construção híbrida, ao mesmo tempo em que a composição dos sujeitos também auxilia a estabelecer a alteridade expressa na linguagem martineziana, através de um "eu" que problematiza a ficção e o que é verossímil, a partir de olhares questionadores, bem como da inserção de outros gêneros, linguagens e temporalidades no discurso romanesco. 


\section{REFERÊNCIAS}

BERND, Zilá (2007). "Recém-nascido". In: BERND, Zilá. Dicionário de figuras e mitos literários das Américas. Porto Alegre: Editora da Universidade. p.547-551. CAMPI, Daniel (2003). "Azúcar y trabajo. Coacción y mercado laboral en Tucumán". Población \& sociedad, (10-11). 250-252. In http://dialnet.unirioja.es/ servlet/articulo?codigo=326581 Acesso em 19.0ut.2015.

CANCLINI, Néstor García (2003). Culturas híbridas: estratégias para sair da modernidade. Heloísa Pezza Cintrão \& Ana Regina Lessa (Trad.)2. ed. Gêneses. 4.ed. São Paulo: Editora da USP.

CARMONA, Virgílio (1968). "Al Jardín de la República". In Con sabor a Mercedes Sosa. Buenos Aires: Philips. Faixa 6.

CHEVALIER, Jean (1994). Dicionário de símbolos: mitos, sonhos, costumes, gestos, formas, figuras, cores, números. 8.ed. Rio de Janeiro: José Olympio.

CHIAMPI, Irlemar (1980). O realismo maravilhoso. São Paulo: Perspectiva.

CUNHA, Rubelise da (2007). "Trickster" In: BERND, Zilá. Dicionário de figuras e mitos literários das Américas. Porto Alegre: Editora da Universidade. p.641-647. ESTEVES, Antonio R.; FIGUEIREDO, Eurídice (2010). "O realismo mágico e o realismo maravilhoso". In: FIGUEIREDO, Eurídice (Orgs.). Conceitos de literatura e cultura. Juiz de Fora, Editora da UFJF. p.393-414.

GRANILLO, Arsenio (1872). Provincia de Tucumán. Tucumán, Imprenta de la Razón. GÜEMES, César (1997). "Argentina, en el engaño de creerse en Europa y no en América Latina: Eloy Martínez", La Jornada, México, 19 de oct 1997. In http:// www.jornada.unam.mx/1997/oct97/971019/eloy.html Acesso em: 20.Nov.2014. HANCIAU, Nubia Jacques (2007). "Feiticeiria". In: BERND, Zilá. Dicionário de figuras e mitos literários das Américas. Porto Alegre: Editora da Universidade. p.282-288.

KARAM, Henriete (2007). "Paraíso". In: BERND, Zilá. Dicionário de figuras e mitos literários das Américas. Porto Alegre: Editora da Universidade. p.506-511.

LAROCHE, Maximilien (2007). "Zombi". In: BERND, Zilá. Dicionário de figuras e mitos literários das Américas. Porto Alegre: Editora da Universidade. p.687-692. MARTÍNEZ, Tomás Eloy (1969). Sagrado. Buenos Aires: Editorial Sudamericana. 
PERILLI, Carmen (2010). “La patria entre naranjos y cañaverales. Tucumán y el primer centenario". Revista Pilquen, Universidad Nacional del Comahue, 12(12), 1-9.

. "Tomás Eloy Martínez, el gran peronólogo". In La Gaceta. In http:// www.lagaceta.com.ar/nota/634927/la-gaceta-literaria/tomas-eloy-martinezgran-peronologo.html Acesso em: 22.Dez.2015.

ZILBERMAN, Regina (1994). "Natureza, lucro e paraíso". In: . A terra em que nasceste: imagens do Brasil na literatura. Porto Alegre: Editora da UFRGS. p.12-34. 